\title{
An Investigation of the Macroeconomic Factors Affecting the Indian Stock Market
}

\author{
Dr. Pooja Misra ${ }^{1}$
}

\begin{abstract}
The economic growth of India has positioned it as one of the rapidly growing economies the world over and it is expected to be one of the top three economies globally over the next decade. Contrary to a slowdown in the earnings of Indian corporates due to excess existing capacity and the inability of banks to lend, the stock market ie Bombay Stock Exchange has performed well. The objective of the present research is to investigate the link that exists, if any, between BSE Sensex and macroeconomic variables such as Index of Industrial Production (IIP), inflation, the rate of interest, the price of gold, rate of exchange, FII and supply of money for the period April 1999-March 2017. The study also seeks to determine the strength of the link between the independent parameters and the dependent parameter ie BSE Sensex in the short run and long run based on the test of Johansen Cointegration, Granger Causality, and the Vector Error Correction mechanism. The analysis through the Vector Error Correction Model (VECM) confirms that there exists a long-run causality between the macroeconomic variables of Index of Industrial Production (IIP), inflation, interest rates, gold prices, exchange rate, foreign institutional investment, money supply and BSE Sensex. It establishes that there does exist a short run causality between Inflation and BSE Sensex and Money Supply and BSE Sensex. The results importantly show that BSE Sensex causes changes in the exchange rate and money supply, FII, gold prices and IIP.
\end{abstract}

JEL Classification: G10, E63.

Keywords: Bombay Stock Exchange, Macroeconomic variables, Johansen Cointegration, Granger Causality, and the Vector Error Correction Model.

\footnotetext{
${ }^{1}$ Associate Professor, Birla Institute of Management Technology, Plot No. 5, Knowledge Park - II, Greater NOIDA, UP - 201306; email address: pooja.misra@bimtech.ac.in Assistant Professor, IBS Hyderabad, India.
} 


\section{Introduction}

The economic growth of India has positioned it as one of the fastest growing economies across the world and is expected to be in the list of top three economies over the next ten years. India's Gross Domestic Product has increased by 7.1\% in 2016-17, whilst in 2016-17 the projection is of $7 \%$. Indian Corporate earnings are anticipated to rise by more than $20 \%$ in 2017-18. After 14 years Moody's has upgraded India's sovereign rating to Baa2 based on a stable economic outlook. The robust performance of the financial and stock markets have a positive bearing on the fundamentals of an economy and help in the establishment of an efficient financial and economic system in a country. Macroeconomic variables such as Index of Industrial Production (IIP), interest rates, inflation levels, the price of gold, the rate of exchange, FII and supply of money are known to impact the performance of the stock markets.

Liberalisation and privatisation in 1991 permitted Foreign Institutional Investors to invest in Indian debt and equity markets from 1992 onwards. Through the primary market, in 2017 Indian corporates raised Rs 1.6 trillion (US\$ 24.96 billion). For April-October 2017, there has been an inflow of USD 17.412 million through FIIs and US\$ 43.4 billion in 2016-17 through Foreign Direct Investment (FDI). As per the mid-year Indian Economic Survey, due to the liberalisation and privatisation measures, India has received the highest equity inflow and is one of the most open global economies in the World. With the Indian Government's slew of economic measures in the past few months, investors are optimistic and upbeat about the Indian economy. Demonetisation and implementation of the Goods and Services Tax measures by the Government have increased the confidence of investors in the Indian stock markets. With SEBI relaxing the regulations for registered Foreign Portfolio investments in India and permitting them to invest in infrastructure investment trusts and Real Estate Investment Trusts, Corporates have a positive outlook on the Indian economy.

The stock market of India is recognised to be amongst the most developed capital market world over. It is the Bombay Stock Exchange (BSE) and the National Stock Exchange (NSE) which are known to be the main Indian stock exchanges. Bombay Stock Exchange which was set up in 1875 is the first Asian stock exchange. It has over 5000 Companies listed on it. It's the BSE Sensex - BSE's equity index which is known to be a widely tracked and an accepted stock-market benchmark equity index. The BSE index is said to be reflective of the health of the Indian economy. It is India's largest stock market for listed companies and market capitalisation and almost every leading corporate is listed in the BSE. In February 2017, BSE became India's first listed stock exchange. The National Stock market index was set-up in 1992 November and became a recognised stock exchange in April 1993. It is one of the leading stock exchanges in India. The National Stock Exchange began its operations in 1994. (Singh, 1997) states that it is the stock markets which have a key role in a country's economic growth. The Indian equity market is known to have done well mainly due to a synchronized recovery in the global economy. Contrary to a slowdown in the earnings of Indian corporates due to excess existing capacity and the inability of banks to lend, the stock market has performed well.

Volatility in any stock market should be minimized as it is a measure of risk. Volatility is driven by the arrival of new information regarding different macroeconomic factors or any kind of private information which can be incorporated into stock market prices. Volatility is caused by factors such as changes in inflation levels, interest rates, IIP, money supply etc. Reserve Bank of India's main policy objective is to maintain inflation levels around $4 \%$. RBI's focus on inflation targeting influences its decision of a change to the key interest rates 
in the country. The demand of interest rate cuts by the industry for purposes of capital formation at times warrants other measures to be adopted by the Government through reforms that can improve the competitiveness of Indian products. The impact of the Money supply, Foreign Institutional Investments, REER, IIP, in terms of interest the Call Money Rate (CM), WPI and Prices of Gold on the Bombay Stock Exchange (BSE) Sensex was studied by (Chittedi, 2015). He investigated the relationship between these macroeconomic drivers and the BSE. The link between macroeconomic drivers and BSE was studied by (Singh, 2014) ie influence of WPI, Money Supply, IIP, Interest rate, trade deficit, Exchange rate, FII, prices of crude oil and gold price. The study showed a substantial impact of the macroeconomic drivers on the Indian stock market. Exchange rate and Gold prices were seen to have a negative impact, whilst supply of money and investment from abroad have a positive impact. It was the test of Granger causality which showed a causal relationship which traverses from exchange rate to the stock market.

\section{Research Objective:}

There could be varying factors such as IIP, inflation, the rate of interest, the price of gold, the rate of exchange, FII and supply of money etc which could be influencing the stock market indices in India ie BSE Sensex.

1. The present research study investigates the link that exists, if any, between BSE Sensex and macroeconomic variables such as Index of Industrial Production (IIP), inflation, the rate of interest, the price of gold, the rate of exchange, FII and supply of money for the period April 1999 - March 2017.

2. The study also seeks to determine the strength of the link between the independent parameters and the dependent parameter ie BSE Sensex in the short run and long run based on the test of Granger Causality, and the Vector Error Correction model.

\section{Literature Review}

In his research, (Ahmed, 2008) studied the impact of broad money supply, IIP, the rate of interest, exchange rates and FDI on the stock market index and found a causal link between some macroeconomic parameters and the long run stock market index. On the other hand, (Srivastava, 2010) found that it was the wholesale price index and rate of interest which influences the stock market indices and found that it was the domestic variables which have a larger impact than global variables. They used the test of Johansen Cointegration and VECM for analytical purposes. The impact of macroeconomic variables such as rate of exchange, inflation, IIP, M3, prices of gold, silver, and oil on the Bombay Stock exchange S\&P CNX Nifty was studied by (Patel, 2012). He applied the test of the uit root, ie the ADF, Johansen Cointegration test, VECM and test of Granger Causality for January 1991 to December 2011. He found that is a long run relationship between the macroeconomic parameters and the Sensex. He also found that the causal relation is from the rate of exchange to the performance of the stock market to IIP and price of oil.

The impact of economic variables such as Money Supply, call money, prices of crude oil, exchange rate, foreign exchange reserves, FIIs, gross fiscal deficit, IIP, inflation and balance of trade was studied by (Gurloveleen \& Bhatia, 2015). They tested the same through the multiple regression technique, ADF test and test of causality by the Granger Causality and found that amongst all FFIs and Exchange rate were the highest influencing factors.

In case of the link between Foreign Institutional Investors and the stock market of India (Hojatullah \& Ramanarayana, 2011), used the Engle-Granger test and Johansen Cointegration 
and established the fact that FII and BSE stock index were cointegrated and a bilateral causality existed. In their research (Hosseini, 2011) studied the causal relationship between stock prices and macroeconomic parameters studied prices of crude oil, the supply of money, inflation and IIP and found that both in the short and long run there is a link between the stock market index and macroeconomic variables. They applied the ADF test, Johansen Julius Multivariate Cointegration, and Vector Error Correction mechanism.

The impact of changes of crude oil prices and the exchange rate on Indian economic growth levels was researched by (Bhunia, 2012) and found that it was the growth of GDP which was impacted by stock prices rates, oil prices and exchange rate but the most impacting factor amongst the three was increase in stock prices. The relationship between CRR, reverse repo rate, prices of gold and silver, inflation, WPI, GDP and foreign exchange rates and the Indian stock market was studied by (Kalra, 2012). It was seen that WPI, forex, inflation and gold prices was the most significant. (Naik, 2012) in his study used the Johansen Cointegration, the test of Granger Causality and VECM model to study the link between stock market returns in BSE Sensex and IIP, money supply, WPI, treasury bill rates and exchange rates. He found a long run relationship between the macroeconomic parameters and stock market returns and found that stock prices and IIP and money supply have a direct relationship whilst it is inversely related to price levels.

The impact on BSE and NSE was researched by (Sangmi \& Hassan, 2013) and influence of factors such as exchange rate, inflation levels, IIP, broad money supply, gold price and interest rates on the stock exchange ie BSE and Nifty were studied. It was found that there exists a significant connection between the dependent and independent parameters. (Shanken \& Mark, 2006) in their study found that IIP is a major influencing factor impacting the stock market.

The active relationship between the exchange rate and the stock market in the short run and long run for 2005-2014 was studied by (Polisetty, Kumar, \& Kurian, 2016) studied the. They found no impact or influencing factors between the two variables. It was found by (Sanningammanavara, Kiran Kumar, \& Rakesh, June 2014) that it was the rupee depreciation and consistent increase in price levels which led to a fall in the share prices. In addition, macroeconomic variables such as market outlook and sentiments, the rate of interest, global factors, the performance of Corporates also has a bearing on the share prices and stock market results. In their study of macroeconomic variables and American stock prices (Geske \& Roll, 1983) found an inverse relationship between the prices of Company stocks and rise in general price levels in the country. On researching, (Mukherjee \& Naka, 1995) found that stock results in Japan are linked to the existing economic activity in the country, money supply, inflation, long-term government bond rate, interest rate and exchange rate. In their study (Upadhyay, October 2016) found that there is no underlying relationship between interest rates and returns on the stock markets. The author investigated the same through the test of Granger Causality. In his study of three countries ie Sri Lanka, India and Pakistan (Aurangzeb, Sept 2012) used regression analysis technique and found that both FDI and exchange rate have a positive influence on the performance of stock markets in S Asia while the rate of interest has a negative impact.

The perception of brokers with reference to factors affecting Indian stock prices which in turn has a bearing of investment decisions through the varimax rotated factor matrix was studied by (Sainy, 2016). They found variables such as economic environment (demand and supply, sound financial system, time of harvest, EPS of the company, market capitalization, natural calamity), policies of the Government and GDP(GDP, inflation, liquidity), balance of 
payment, policies of SEBI, disclosures (transparency, disinvestment of PSU), and liberalization which in the minds of the brokers impacts Indian stock prices.

The variables which influenced the stock exchange of Zimbabwe was assessed by (Njanike, Katsuro, \& Mudzura, 2009) and it was found that it was driven by speculation as the aim of the investors was to hedge against inflation. It has been stated by (Ibrahim \& Aziz, 2003) that the stock market outcome is impacted by influence. Based on average monthly data 20012013 (Kumar, 2013) used the technique of factor analysis to derive variables that impact the Indian stock market. The variables considered were consumer price index, broad money, prices of gold and crude oil, foreign exchange reserves, FDI, FII, call money rate, trade balances, foreign exchange rate, repo rate and industrial growth rate. The factor analysis showed that three factors were able to explain $79 \%$ of the variance primarily macro environment, industrial performance and policy rates. Under macroenvironment variables, factors such as consumer price index, broad money, prices of gold and crude oil, foreign exchange reserves, FDI, FII, trade balances grouped, under industrial performance factors such as Foreign Exchange Rate and Industrial Growth Rate grouped and under policy rates repo rate and Call Money Rate grouped. In their studied (Chen, Roll, \& Ross, 1986) state that macroeconomic variables affect stock market behaviour. It was also seen by (Chen, 1983) that generally there are three to five macroeconomic factors extracted which explain the relationship.

In his research (Fama, 1981) considered the economic variables whilst (Connor \& Korajczyk, 1986) studied financial variables to assess the impact they have on the performance of the stock market.

The relationships in the short run and long run was studied by (Kotha \& Sahu, 2016) between macroeconomic drivers and returns on Indian stock market through co-integration and vector error correction models for the period 2001-2015 and found a long run link between BSE Sensex and treasury bill rates, WPI, exchange rate and money supply. They also stated that macroeconomic variables are those variables which reflect the general economic conditions and are linked to interest rates, monetary and international policy decision making. In their study on Sri Lanka (Gunasekarage, Pisedtasalasai, \& Power, 2004) researched the influence of factors such as the supply of money, T bill, CPI, the exchange rate on the stock exchange. They used statistical tools such as VECM, impulse response function and found that in the long run, CPI, the supply of money and rate of interest has an important bearing on the stock market. As per the researchers, interest rate influences stick markets and is also influenced by the stock market in turn. It was found by (Sohail \& Hussain, 2009) that supply of money and stock prices have a direct link whilst rate of interest and prices of stocks are inversely related ie a decline in the rate of interest takes down the borrowing cost for firms and thereby has a positive influence on stock prices. In their research (Gjerde \& Saettem, 1999) found the rate of interest and prices of stocks to be inversely linked while the rate of exchange and returns on the stock markets are directly linked.

\section{Research Gap}

Based on Literature Review it was concluded that there exists a relationship between macroeconomic variables and performance of the stock market. However, the present study seeks to extend the extant literature in the Indian context for the period from April 1999March 2017. The study endeavours to investigate the link that exists, if any, between BSE Sensex and macroeconomic variables such as Index of Industrial Production (IIP), inflation, the rate of interest, the price of gold, the rate of exchange, FII and supply of money. In addition, the strength of the relationship is determined between the macroeconomic drivers 
and BSE Sensex based on the test of Johansen Cointegration, Granger Causality, and Vector Autoregression model / Vector Error Correction model. The findings of the study will have important and key policy implications.

\section{Hypothesis:}

Null Hypothesis:

H01: IIP does not have an impact on BSE Sensex.

H02: Inflation does not have an impact on BSE Sensex.

H03: Interest Rates does not have an impact on BSE Sensex.

H04: Gold Prices does not have an impact on BSE Sensex.

H05: Exchange Rate does not have an impact on BSE Sensex.

H06: FIIs does not have an impact on BSE Sensex.

H07: Money Supply does not have an impact on BSE Sensex.

Alternate Hypothesis:

Null Hypothesis:

H01: IIP does have an impact on BSE Sensex.

H02: Inflation does have an impact on BSE Sensex.

H03: Interest Rates does have an impact on BSE Sensex.

H04: Gold Prices does have an impact on BSE Sensex.

H05: Exchange Rate does have an impact on BSE Sensex.

H06: FIIs does have an impact on BSE Sensex.

H07: Money Supply does have an impact on BSE Sensex.

\section{Research Methodology}

Quarterly data for the period April 1999-March 2017 was sourced from the Economic Survey, worldbank.org, trading economic.com and indiastats.com. The independent variables considered were Index of Industrial Production (IIP), inflation, the rate of interest, the price of gold, the rate of exchange, FII and supply of money. Eviews was used for purposes of mathematical and statistical analysis.

\section{Tests}

Keeping in mind that the data is time series in nature it is important to test for Unit Root / to determine whether the data is stationary or not by applying the Augmented Dickey-Fuller test on each independent parameter. In case there exists a Unit Root, the series is to be differentiated and tested for being stationary. In the case of cointegration, the test of Johannsen Cointegration was conducted. In addition, the Granger Causality test was also done to establish the causal effect if any between each independent parameter and the dependent parameter ie BSE Sensex. Thereafter in case of the existence of cointegration, it is advisable to administer the Vector Error Correction model (VECM) as against the unrestricted vector autoregressive model (VAR). The mathematical and statistical analysis was done by Eviews.

Thus, the model can be defined as:

BSE $=$ C1+C2 (IIP)+C3 (INFLATION)+C4 (INTEREST RATES)+C5 (GOLD PRICES) +C6 (EXCHANGE RATE) +C7 (FOREIGN INSTITUTIONAL INVESTMENT) +C8 (MONEY SUPPLY) $+e_{t}$

\section{Data Analysis and Results:}

On conducting the Augmented Dickey-Fuller test on the level data it was observed that FII was stationary and the other independent variables were not. Subsequently, the data was 
differentiated and tested for the Augmented Dickey-Fuller test, thereafter the data was found to be stationary or having no unit root. Thus, the first difference of the series for each of the variables other than FII was computed.

After conducting the Augmented Dickey-Fuller test, the Johannsen Cointegration test was done to check for a long-run association between the variables. The test for Johannsen Cointegration assesses for whether the parameters have a long-run relationship or are cointegrated or not. The basic assumption in the case of Johansen cointegration is that the variables must be non-stationary. The test for Johansen Cointegration showed that there are 5 cointegrating equations and there exists a long-run association amongst the variables at 5\% level. In case the variables are cointegrated the recommendation is to run a Vector Error Correction model. However, if they are not cointegrated then VAR model should be run. Thus the Vector Error Correction model was run for the sample.

Date: $11 / 23 / 17$ Time: $14: 46$

Sample (adjusted): 2000Q2 2017Q1

Included observations: 68 after adjustments

Trend assumption: Linear deterministic trend

Series: BSE EXCHANGERATE FII GOLDPRICES IIP INFLATION INTERESTRATE MONEYSUPPLY

Lags interval (in first differences): 1 to 3

Unrestricted Cointegration Rank Test (Trace)

\begin{tabular}{ccccc}
\hline \hline $\begin{array}{c}\text { Hypothesized } \\
\text { No. of CE(s) }\end{array}$ & Eigenvalue & $\begin{array}{c}\text { Trace } \\
\text { Statistic }\end{array}$ & $\begin{array}{c}0.05 \\
\text { Critical Value }\end{array}$ & Prob. $^{* *}$ \\
\hline \hline None * & 0.724585 & 296.9063 & 159.5297 & 0.0000 \\
At most 1 * & 0.636592 & 209.2219 & 125.6154 & 0.0000 \\
At most 2 * & 0.503288 & 140.3902 & 95.75366 & 0.0000 \\
At most 3 * & 0.401610 & 92.80751 & 69.81889 & 0.0003 \\
At most 4 * & 0.344012 & 57.88862 & 47.85613 & 0.0043 \\
At most 5 & 0.194995 & 29.21896 & 29.79707 & 0.0582 \\
At most 6 & 0.151701 & 14.46929 & 15.49471 & 0.0709 \\
At most 7 & 0.047115 & 3.281775 & 3.841466 & 0.0700 \\
\hline \hline
\end{tabular}

Trace test indicates 5 cointegrating eqn(s) at the 0.05 level

Unrestricted Cointegration Rank Test (Maximum Eigenvalue)

\begin{tabular}{ccccc}
\hline \hline $\begin{array}{c}\text { Hypothesized } \\
\text { No. of CE(s) }\end{array}$ & Eigenvalue & $\begin{array}{c}\text { Max-Eigen } \\
\text { Statistic }\end{array}$ & $\begin{array}{c}0.05 \\
\text { Critical Value }\end{array}$ & Prob. $^{* *}$ \\
\hline \hline None * & 0.724585 & 87.68449 & 52.36261 & 0.0000 \\
At most 1 * & 0.636592 & 68.83166 & 46.23142 & 0.0001 \\
At most 2 * & 0.503288 & 47.58269 & 40.07757 & 0.0060 \\
At most 3 & 0.401610 & 34.91889 & 33.87687 & 0.0374 \\
At most 4 * & 0.344012 & 28.66966 & 27.58434 & 0.0362 \\
At most 5 & 0.194995 & 14.74967 & 21.13162 & 0.3068 \\
At most 6 & 0.151701 & 11.18752 & 14.26460 & 0.1451 \\
At most 7 & 0.047115 & 3.281775 & 3.841466 & 0.0700 \\
\hline \hline
\end{tabular}

Max-eigenvalue test indicates 5 cointegrating eqn(s) at the 0.05 level 
Using trace statistics and the max eigenvalue test indicated that there are 5 cointegration equations at the 0.05 level or in the long run the variables have an association.

\section{Vector Error Correction Model}

Thus based on the outcome of the ADF and Johansen Cointegration test it was seen that there exists a long-run relationship between the independent variables and the dependent variable ie BSE Sensex. Thus, it is recommended to develop the Vector Error Correction model.

\begin{tabular}{|c|c|c|c|c|}
\hline \multicolumn{5}{|c|}{ Dependent Variable: D(BSE) } \\
\hline \multicolumn{5}{|c|}{ Method: Least Squares } \\
\hline \multicolumn{5}{|c|}{ Date: $11 / 23 / 17$ Time: $14: 51$} \\
\hline \multicolumn{5}{|c|}{$\begin{array}{l}\text { Sample (adjusted): 2000Q2 2017Q1 } \\
\text { Included observations: } 68 \text { after adjustments }\end{array}$} \\
\hline \multicolumn{5}{|c|}{ Included observations: 68 after adjustments } \\
\hline \multicolumn{5}{|c|}{$D(B S E)=C(1) *(B S E(-1)+156815.393741 * I N F L A T I O N(-1)-$} \\
\hline \multicolumn{5}{|c|}{ 1057981.65523*INTERESTRATE(-1) + 0.171557844386} \\
\hline \multicolumn{5}{|c|}{ *MONEYSUPPLY $(-1)+6064429.90889)+\mathrm{C}(2) \star($ EXCHANGERATE $(-1)$} \\
\hline \multicolumn{5}{|c|}{ + 110.646549346*INFLATION(-1) - 743.96007681*INTERESTRATE(-1) } \\
\hline \multicolumn{5}{|c|}{ + 8.61684197453E-05*MONEYSUPPLY(-1) + 4258.6561997 ) +C(3)*( } \\
\hline \multicolumn{5}{|c|}{ FII(-1) + 2099.63520117*INFLATION(-1) - 18218.2605291} \\
\hline \multicolumn{5}{|c|}{ *INTERESTRATE(-1) - 0.00150900346289*MONEYSUPPLY(-1) + } \\
\hline \multicolumn{5}{|c|}{$109666.875626)+C(4) \star($ GOLDPRICES $(-1)+5879.37225548$} \\
\hline \multicolumn{5}{|c|}{ *INFLATION(-1) - 40255.5571117*INTERESTRATE(-1) + } \\
\hline \multirow{2}{*}{\multicolumn{5}{|c|}{$\begin{array}{l}0.00523957756504 * \text { MONEYSUPPLY }(-1)+232375.704227)+\mathrm{C}(5) *( \\
\text { IIP }(-1)+244.668281367 * \text { INFLATION }(-1)-1622.66312674\end{array}$}} \\
\hline & & & & \\
\hline \multicolumn{5}{|c|}{ *INTERESTRATE $(-1)+0.000450480681994 *$ MONEYSUPPLY(-1) + } \\
\hline \multicolumn{5}{|c|}{$8891.39279338)+\mathrm{C}(6)^{\star} \mathrm{D}(\mathrm{BSE}(-1))+\mathrm{C}(7) \star \mathrm{D}(\mathrm{BSE}(-2))+\mathrm{C}(8) \star \mathrm{D}(\mathrm{BSE}($} \\
\hline \multicolumn{5}{|c|}{$-3))+C(9) * D($ EXCHANGERATE $(-1))+C(10) * D($ EXCHANGERATE $(-2))+$} \\
\hline \multirow{2}{*}{\multicolumn{5}{|c|}{$\begin{array}{l}\mathrm{C}(11)^{\star} \mathrm{D}(\text { EXCHANGERATE }(-3))+\mathrm{C}(12)^{\star} \mathrm{D}(\mathrm{FII}(-1))+\mathrm{C}(13)^{\star} \mathrm{D}(\mathrm{FII}(-2))+ \\
\mathrm{C}(14)^{*} \mathrm{D}(\mathrm{FII}(-3))+\mathrm{C}(15) * \mathrm{D}(\mathrm{GOL} \text { PRICES}(-1))+\mathrm{C}(16)\end{array}$}} \\
\hline & & & \multicolumn{2}{|c|}{$C(14) \star D(F I I(-3))+C(15) * D(G O L D P R I C E S(-1))+C(16)$} \\
\hline \multirow{2}{*}{\multicolumn{5}{|c|}{$\begin{array}{l}* \mathrm{D}(\text { GOLDPRICES }(-2))+\mathrm{C}(17)^{*} \mathrm{D}(\text { GOLDPRICES }(-3))+\mathrm{C}(18)^{*} \mathrm{D}(\mathrm{IIP}(-1)) \\
+\mathrm{C}(19)^{\star} \mathrm{D}(\mathrm{IIP}(-2))+\mathrm{C}(20)^{*} \mathrm{D}(\mathrm{IIP}(-3))+\mathrm{C}(21)^{\star} \mathrm{D}(\mathrm{INFLATION}(-1))+\mathrm{C}(22)\end{array}$}} \\
\hline & & & & \\
\hline \multicolumn{5}{|c|}{${ }^{*} \mathrm{D}(\mathrm{INFLATION}(-2))+\mathrm{C}(23){ }^{*} \mathrm{D}(\mathrm{INFLATION}(-3))+\mathrm{C}(24)$} \\
\hline${ }^{*} \mathrm{D}(\mathrm{INTERE}$ & 1)) $+C(25) \star[$ & TERESTRA & $E(-2))+C(26$ & \\
\hline${ }^{*} \mathrm{D}$ (INTERE & $3))+C(27) \star[$ & NEYSUP & $(-1))+C(28$ & \\
\hline${ }^{*} \mathrm{D}(\mathrm{MONEY}$ & )$)+C(29)^{*}$ & & (2) & \\
\hline & Coefficient & Std. Error & t-Statistic & Prob. \\
\hline$C(1)$ & -0.160681 & 0.060012 & -2.677475 & 0.0109 \\
\hline$C(2)$ & -23.5300 & 57.47909 & 2.149130 & 0.0381 \\
\hline$C(3)$ & -0.007902 & 0.106337 & 0.074309 & 0.0412 \\
\hline$C(4)$ & -0.783580 & 1.658721 & 0.472400 & 0.0393 \\
\hline$C(5)$ & -28.43223 & 9.704919 & 2.929673 & 0.0057 \\
\hline$C(6)$ & 0.052033 & 0.205795 & 0.252837 & 0.8018 \\
\hline$C(7)$ & -0.443020 & 0.221719 & -1.998117 & 0.0529 \\
\hline$C(8)$ & 0.226679 & 0.231554 & 0.978949 & 0.3338 \\
\hline$C(9)$ & 249.2087 & 172.5149 & 1.444564 & 0.1568 \\
\hline$C(10)$ & -381.5653 & 179.8903 & -2.121100 & 0.0405 \\
\hline$C(11)$ & 112.0507 & 197.4508 & 0.567487 & 0.5737 \\
\hline$C(12)$ & 0.049619 & 0.089002 & 0.557505 & 0.5805 \\
\hline$C(13)$ & 0.034576 & 0.060875 & 0.567992 & 0.5734 \\
\hline$C(14)$ & 0.018746 & 0.038835 & 0.482706 & 0.6321 \\
\hline$C(15)$ & -0.361973 & 3.400645 & -0.106443 & 0.9158 \\
\hline$C(16)$ & 1.797919 & 4.985032 & 0.360663 & 0.7203 \\
\hline$C(17)$ & -2.217043 & 4.229343 & -0.524205 & 0.6032 \\
\hline$C(18)$ & -19.88220 & 11.82284 & -1.681678 & 0.1008 \\
\hline$C(19)$ & -18.34849 & 10.01760 & -1.831625 & 0.0749 \\
\hline$C(20)$ & -7.631968 & 10.18602 & -0.749259 & 0.4583 \\
\hline$C(21)$ & -429.6792 & 165.2552 & -2.600094 & 0.0132 \\
\hline
\end{tabular}




\begin{tabular}{lrrrr} 
C(22) & -162.3728 & 148.6080 & -1.092625 & 0.2814 \\
C(23) & -200.3147 & 134.7735 & -1.486307 & 0.1454 \\
C(24) & 134.8228 & 508.7425 & 0.265012 & 0.7924 \\
C(25) & 193.3833 & 479.4259 & 0.403364 & 0.6889 \\
C(26) & -16.45293 & 492.6148 & -0.033399 & 0.9735 \\
C(27) & 0.001199 & 0.000437 & 2.742568 & 0.0092 \\
C(28) & 0.001142 & 0.000372 & 3.073003 & 0.0039 \\
C(29) & 0.000801 & 0.000403 & 1.988695 & 0.0540 \\
C(30) & 499.2404 & 248.0114 & 2.012974 & 0.0512 \\
\hline \hline R-squared & 0.649011 & Mean dependent var & 344.9325 \\
Adjusted R-squared & 0.381151 & S.D. dependent var & 1402.570 \\
S.E. of regression & 1103.359 & Akaike info criterion & 17.15054 \\
Sum squared resid & 46261246 & Schwarz criterion & 18.12973 \\
Log likelihood & -553.1183 & Hannan-Quinn criter. & 17.53852 \\
F-statistic & 2.422949 & Durbin-Watson stat & 1.987480 \\
Prob(F-statistic) & 0.005480 & & \\
\hline \hline
\end{tabular}

The VECM showed that the R square for the model strong and is $64.90 \%$ and Prob (F statistic) is 0., Durbin Watson statistics was 1.98. It was established that the model has no serial correlation and no autocorrelation. The serial correlation was checked based on Breusch Godfrey Serial Correlation LM test. The results show that the VECM developed is strong and there exists a long-run relationship between the independent parameters and the dependent parameter.

Breusch-Godfrey Serial Correlation LM Test:

\begin{tabular}{llll}
\hline \hline F-statistic & 0.611569 & Prob. F(2,36) & 0.5480 \\
Obs*R-squared & 2.234455 & Prob. Chi-Square(2) & 0.3272 \\
\hline \hline
\end{tabular}

\section{Long Run causality:}

$C(1), C(2), C(3), C(4)$ and $C(5)$ are the error correction term or speed of adjustment towards equilibrium. Long run causality requires $C(1), C(2), C(3), C(4)$ and $C(5)$ to be negative in sign and significant. Since the same is significant and has a negative sign it shows that there is long-run causality between the independent variable of Index of Industrial Production (IIP), inflation, interest rates, gold prices, exchange rate, foreign institutional investment, money supply and BSE Sensex

\section{Short Run Causality:}

The Wald test was used to check for the causality in the short run between the independent and dependent parameters. The guideline for the same is that for causality to exist in the short run Chi-Square has to be less than $5 \%$ in the Wald test.

The test showed that there exists no causality in the short run between the rate of Exchange and BSE Sensex, FII and BSE Sensex, Gold prices and BSE Sensex, IIP and BSE Sensex, Interest Rate and BSE Sensex.

However, there does exist a short run causality between Inflation and BSE Sensex and Money Supply and BSE Sensex

\section{Exchange Rate}

Wald Test:

Equation: Untitled 
AABFJ | Volume 12, no. 2, 2018

\begin{tabular}{lccc} 
Test Statistic & Value & df & Probability \\
\hline \hline F-statistic & 1.928865 & $(3,38)$ & 0.1413 \\
Chi-square & 5.786594 & 3 & 0.1225 \\
\hline \hline
\end{tabular}

FII

Wald Test:

Equation: Untitled

\begin{tabular}{lccc}
\hline \hline Test Statistic & Value & df & Probability \\
\hline \hline F-statistic & 0.121478 & $(3,38)$ & 0.9469 \\
Chi-square & 0.364434 & 3 & 0.9475 \\
\hline \hline
\end{tabular}

Gold Prices

Wald Test:

Equation: Untitled

\begin{tabular}{lccc}
\hline \hline Test Statistic & Value & df & Probability \\
\hline \hline F-statistic & 0.176742 & $(3,38)$ & 0.9115 \\
Chi-square & 0.530225 & 3 & 0.9122 \\
\hline \hline
\end{tabular}

IIP

Wald Test:

Equation: Untitled

\begin{tabular}{lccc}
\hline \hline Test Statistic & Value & df & Probability \\
\hline \hline F-statistic & 1.333562 & $(3,38)$ & 0.2778 \\
Chi-square & 4.000687 & 3 & 0.2614 \\
\hline \hline
\end{tabular}

Inflation

Wald Test:

Equation: Untitled

\begin{tabular}{lccc}
\hline \hline Test Statistic & Value & df & Probability \\
\hline \hline F-statistic & 2.626368 & $(3,38)$ & 0.0443 \\
Chi-square & 7.879104 & 3 & 0.0486 \\
\hline \hline
\end{tabular}

Interest Rate

Wald Test:

Equation: Untitled

\begin{tabular}{lccc}
\hline \hline Test Statistic & Value & df & Probability \\
\hline \hline F-statistic & 0.081097 & $(3,38)$ & 0.9699 \\
Chi-square & 0.243291 & 3 & 0.9703 \\
\hline \hline
\end{tabular}

Money Supply 
Wald Test:

Equation: Untitled

\begin{tabular}{lccc}
\hline \hline Test Statistic & Value & df & Probability \\
\hline \hline F-statistic & 5.652483 & $(3,38)$ & 0.0026 \\
Chi-square & 16.95745 & 3 & 0.0007 \\
\hline \hline
\end{tabular}

\section{Granger Causality Test}

Subsequently, on conducting the Granger causality test it was seen that with 4 lags exchange rate changes cause an impact or change in BSE but inflation does not cause changes in BSE Sensex and vice versa. With 2 lags BSE causes changes in exchange rate and money supply, 6 lags results in BSE causing a changing in FII, with 5 lags BSE causes a changing in gold prices, 4 lags causes BSE to bring a change in IIP

Pairwise Granger Causality Tests

Date: 11/23/17 Time: 15:36

Sample: 1999Q2 2017Q1

Lags: 2

\begin{tabular}{lccr}
\hline \hline Null Hypothesis: & Obs & F-Statistic & Prob. \\
\hline \hline EXCHANGERATE does not Granger Cause BSE & 70 & 2.46860 & 0.0926 \\
BSE does not Granger Cause EXCHANGERATE & & 3.33776 & 0.0417 \\
\hline \hline
\end{tabular}

Pairwise Granger Causality Tests

Date: 11/23/17 Time: 15:38

Sample: 1999Q2 2017Q1

Lags: 4

\begin{tabular}{lccr}
\hline \hline Null Hypothesis: & Obs & F-Statistic & Prob. \\
\hline \hline EXCHANGERATE does not Granger Cause BSE & 68 & 2.53665 & 0.0494 \\
BSE does not Granger Cause EXCHANGERATE & & 2.63728 & 0.0427 \\
\hline \hline
\end{tabular}

Pairwise Granger Causality Tests

Date: 11/23/17 Time: 15:44

Sample: 1999Q2 2017Q1

Lags: 5

\begin{tabular}{lccr}
\hline \hline Null Hypothesis: & Obs & F-Statistic & Prob. \\
\hline \hline GOLDPRICES does not Granger Cause BSE & 67 & 1.66409 & 0.1584 \\
BSE does not Granger Cause GOLDPRICES & & 2.49285 & 0.0415 \\
\hline \hline
\end{tabular}

Pairwise Granger Causality Tests

Date: 11/23/17 Time: 15:46

Sample: 1999Q2 2017Q1

Lags: 4

\begin{tabular}{lccc}
\hline \hline Null Hypothesis: & Obs & F-Statistic & Prob. \\
\hline \hline BSE does not Granger Cause IIP & 68 & 3.64607 & 0.0101 \\
IIP does not Granger Cause BSE & & 0.26869 & 0.8970
\end{tabular}




\begin{tabular}{|c|c|c|c|}
\hline Null Hypothesis: & Obs & F-Statistic & Prob. \\
\hline MONEYSUPPLY does not Granger Cause BSE & 70 & 0.88342 & 0.4183 \\
\hline BSE does not Granger Cause MONEYSUPPLY & & 9.04096 & 0.0003 \\
\hline
\end{tabular}

\section{Discussion and Conclusion}

The stock market of India stock market is known to be a developed and robust capital market. Bombay Stock exchange in terms of listed companies and market capitalisation is India's largest stock market and almost all Corporates is listed in the BSE. Its the BSE Sensex BSE's equity index which is known to be a widely tracked and an accepted stock-market benchmark equity index. The BSE index is said to be reflective of the health of the Indian economy. (Patel, 2012) studied the impact of variables such as rate of exchange, inflation, IIP, broad money supply, prices of gold, silver, and oil on the Bombay Stock exchange S\&P CNX Nifty. He applied the test of the unit root, ie the ADF, Johansen Cointegration test, VECM and test of Granger Causality for January 1991 to December 2011. He found that there is a long run link amongst the macroeconomic parameters and the Sensex. He also found that the relation of causality is from the exchange rate to stock market indices to IIP and Oil prices.

Based on quarterly data for the period April 1999-March 2017, it was seen that other than FII (data was stationary), the other independent variables had a unit root or were not stationary. The Johansen Cointegration showed that 5 cointegrating equations exist and there is the long run association between the variables at $5 \%$ level. Thereafter the analysis through VECM it is confirmed that there is a long run causality between the independent variables of Index of Industrial Production (IIP), inflation, interest rates, gold prices, exchange rate, foreign institutional investment, money supply and BSE Sensex. R square for the model is $64.90 \%$ and Prob (F statistic) is 0.005 ie it is significant at the 5 level. This corroborates the study done by (Patel, 2012). With a long run relationship being established between the macroeconomic parameters of IIP, inflation, interest rates, gold prices, exchange rate, foreign institutional investment, money supply and BSE Sensex and India being seen by investors as a growing economic power and have tremendous potential it is important that the Government ensures a strong fundamental support to the stock market.

In addition, sustained by strong backing from the government, FII investments have been robust and are expected to continuously be on a rise in the near future. As stated by $\mathrm{Mr}$. Bharat Iyer, MD, Global Research, JP Morgan India, participation by Foreign Institutional investors has been robust and consistent. India in the Asian region and other emerging markets has stood out since November 2013 and the rally still continues.

A report by PricewaterhouseCoopers India has predicted that India has the capacity to woo PE funding to the tune of US\$ 40 billion by 2025. The drivers of these PE investments will primarily be the consumption story, demographic dividends, realistic valuations, competitive 
business positions and growing private entrepreneurship. On the other hand, a tightening of the US monetary policy will hurt portfolio inflows into emerging markets such as India. The tightening of US rates is expected to happen soon. Also, a strong domestic liquidity support thanks to the dedicated money flowing into mutual funds each month through systematic investment plans act as a booster to the Indian stock market environment.

The causality established in the short run between the independent and dependent parameters was checked by the Wald test. The test results stated that there is no sign of a short run causal relationship between the rate of exchange and BSE Sensex, FII and BSE Sensex, Gold prices and BSE Sensex, IIP and BSE Sensex, Interest Rate and BSE Sensex. This is in agreement of the research undertaken by (Polisetty, Kumar, \& Kurian, 2016) who studied the dynamic link between the rate of exchange and the stock market in the short run and long run for 20052014 but found no significant link between the two parameters. However, the analysis conducted for the period April 1999-March 2017 shows that there does exist a short run causality between Inflation and BSE Sensex and Money Supply and BSE Sensex.

Granger causality test showed that with 4 lags exchange rate changes cause an impact or change in BSE but inflation does not cause changes in BSE Sensex and vice versa. Thus, the focus of the RBI should be to maintain a stable exchange rate which in turn has a positive impact on the stock market performance. With 2 lags BSE causes changes in exchange rate and money supply, 6 lags results in BSE causing a changing in FII, 5 lags results in BSE causing a changing in gold prices, 4 lags causes BSE to bring a change in IIP. The current study showed that there does not exist a causal relationship between interest rates and stock market returns which is in tandem with the study by (Upadhyay, October 2016) who found that there exists no causal relationship between interest rates and stock market returns. The author investigated the same through the Granger Causality technique. The results importantly show that BSE Sensex causes changes in the exchange rate and money supply, FII, gold prices and IIP. Keeping the Government's policies in mind, it's focus should be on helping boost corporate earnings and give positive vibes to the stock markets which in turn will have a positive impact on the IIP. Policymakers should take appropriate policy decisions and thereby support industrial growth. Investment in gold is primarily done with a viewpoint of less risky investment. Thus, in a situation of a slowdown, the Government should try to design policies which increase the investor's confidence in business and corporates and thus re-divert the investments from Gold into the corporate markets. Giving a boost to the BSE Sensex will have a positive impact on the exchange rate as it will bring down gold imports and thereby strengthen the currency. Positive change in BSE Sensex will also have a positive influence on the flow of FII money onto India as return on investment in India will be higher for the Foreign Institutional investors thereby, having a positive impact on the Indian economy. Top-line numbers have been modest, return on equity for Corporates and investment in new capacity has been dismal. Markets look ahead-and the most important questions for investors in Indian equities will be the changes in global portfolio flows on the one hand and improvements in corporate financials on the other. Lastly, regulatory authorities, economists and policymakers can definitely contribute and add to the efficient working and performance of the Indian stock market through conducive policy decisions.

\section{Limitations and Scope for Future Research:}

In this research study variables such as crude oil prices has not been analysed. Research in the future can analyse the same. In addition, keeping the financial crisis of 2007-08 in mind, data for the crisis period can be separately analysed. Also, considering that data on a 
quarterly basis has been analysed in future the same research can be conducted with data on a monthly basis.

\section{References}

Ahmed, S. (2008). Aggregate Economic Variables and stock market in India. International Research Journal of Finance and Economics, 14, 141-165.

Aurangzeb, D. (Sept 2012). Factors Affecting Performance of Stock Market: Evidence from South Asian Countries. International Journal of Academic Research in Business and Social Sciences, 2(9), 1-15.

Aydemir, O., \& Demirhan, E. (2009). The Relationship between Stock Prices and Exchange Rate: Evidence from Turkey. International Research Journal of Finance and Economics 23.

Bhunia, A. (2012). The Shock of the shock of Crude Price, Stock price and selected macroeconomic variables on the Growth of Indian Economy. Sumedha Journal of Management, 1, 82-89.

Chen, N. (1983). Some Empirical Tests of the Theory of Arbitrage Pricing, The Journal of Finance, 38(5). https://doi.org/10.1111/j.1540-6261.1983.tb03831.x

Chen, Roll, R., \& Ross, S. (1986). "Economic Forces and the Stock Market, Journal of Business, 59(1).

Chittedi, K. (2015). Macroeconomic Variables impact on Stock Prices in a BRIC Stock Markets: An Empirical Analysis. Journal of Stock Forex Trad, 4(2). https://doi.org/10.4172/2168-9458.1000153

Connor, G., \& Korajczyk, R. (1986). Performance Measurement with the Arbitrage Pricing Theory: A New Framework for Analysis", Journal of Financial Economics, 15(3), 373-394.

Fama, E. F. (1981). Stock Returns, Real Activity, Inflation, and Money. The American Economic Review, 71(4), 545-565.

Geske, R., \& Roll, R. (1983). The fiscal and monetary linkages between stock market returns and inflation. J.Finance, 38-1, 7-33.

Gjerde, O., \& Saettem, F. (1999). Causal relations amongst stock returns and macroeconomic variables in a small, open economy. Journal of International Financial Markets and Money, 9(1), 61-74. https://doi.org/10.1016/S1042-4431(98)00036-5

Gunasekarage, A., Pisedtasalasai, A., \& Power, D. (2004). Macroeconomic influence on the stock market: Evidence from an emerging market in South Asia. Journal of Emerging Market Finance, 3(3), 285-304. https://doi.org/10.1177/097265270400300304

Gurloveleen, K., \& Bhatia, J. (2015). An Impact of Macroeconomic Variables on the functioning of Indian Stock Market: A Study of Manufacturing Firms of BSE 500. Journal of Stock \& Forex Trading, ISSN: 2168-9458 JSFT, 5(1). Retrieved from http://dx.doi.org/10.4172/2168-9458.1000 
Hojatullah, C., \& Ramanarayana, S. (2011). Empirical Analysis of the impact of Foreign Institutional Investment on the Indian Stock Market Volatility during World Financial Crisis. International Journal of Economics and Finance, 3, 214-226.

Hosseini, M. (2011). The Role of Macroeconomic Variables on Stock Market Indices in India and China. International Journal of Economics and Finance, 3, 233-243. https://doi.org/10.5539/ijef.v3n6p233

Ibrahim, M., \& Aziz, H. (2003). Macroeconomics Variables and The Malaysian Equity Market: A View Through the Rolling Subsamples. Journal of Economic Studies, 8, 23-32. https://doi.org/10.1108/01443580310455241

Kalra, R. (2012). Impact of Macroeconomic Variables on Indian Stock Market. IUP Journal of Financial Risk Management IX, 43-54.

Kotha, K., \& Sahu, B. (2016). Macroeconomic Factors and the Indian Stock Market: Exploring Long run and Short run relationships. International Journal of Economics and Financial Issues., 6(3), 1081-1091.

Kumar, R. (2013). The Effect of Macroeconomic Factors on Indian Stock Market Performance: A Factor Analysis Approach. IOSR Journal of Economics and Finance, 1(3), 14-21. https://doi.org/10.9790/5933-0131421

Mukherjee, T., \& Naka, A. (1995). Dynamic relationship between macroeconomic variables and the stock market: An application of Vector Error Correction Model. The Journal of Financial Research: 18, 223-237. https://doi.org/10.1111/j.14756803.1995.tb00563.x

Naik, K. (2012). The Impact of Macroeconomic Fundamentals on Stock Price Revisited: Evidence from Indian Data. Eurasian Journal of Business and Economics, 25-44.

Njanike, K., Katsuro, P., \& Mudzura, M. (2009). Factors influencing the Zimbabwe Stock Exchange Performance (2002-2007). Annals of the University of Petrosani, Economics, 9(2), 161-172.

Patel, S. (2012). The effect of Macroeconomic Determinants on the performance of the Indian Stock Market. NMIMS Management Review, ISSN 09711023, XXII, 117-127.

Patel, S. (2012). The Effect of Macroeconomic Determinants on the performance of the Indian Stock Market. NMIMS Management Review 22, 117-127.

Polisetty, A., Kumar, P. D., \& Kurian, S. J. (2016). Influence of Exchange Rate on BSE Sensex and Nifty. IOSR Journal of Business and Management, 10-15. https://doi.org/10.9790/487X-1809021015

Sainy, R. (2016). A Study of Factors affecting Stock Price Volatility: Perception of Stock Brokers. Intercontinental Journal of Finance Research Review, 4(2).

Sangmi, M., \& Hassan, M. (2013). Macroeconomic variables on Stock Market Interactions: The Indian Experience. IOSR Journal of Business and Management 11, $15-28$. https://doi.org/10.9790/487X-01131528

Sanningammanavara, K., Kiran Kumar, K., \& Rakesh, H. (June 2014). Macro-Economic Forces and Indian St. International Journal of Commerce, Business \& Management, 3(3), 457-465. 
Shanken, J., \& Mark, I. (2006). Weinstein Economic Forces \& the Stock Market revisited. Journal of Empirical Finance 13, 129-144. https://doi.org/10.1016/j.jempfin.2005.09.001

Singh, A. (1997). Financial Liberalization, Stock Markets and Economic Development. The Economist, 771-782.

Singh, P. (2014). Indian Stockmarket and Macroeconomic Factors in Current Scenario. International Journal of Research in Business Management, 2(11), 43-54.

Sohail, N., \& Hussain, Z. (2009). Long-run and short-run relationship between macroeconomic variables and stock prices in Pakistan: The case of Lahore Stock Exchange. Pakistan Economic and Social Review, 47(2), 183-198.

Srivastava, A. (2010). Relevance of Indian Macroeconomic Factors for the Indian Stock Market. 37, 69-89.

Upadhyay, A. (October 2016). Causality Relationship between Interest Rates and Stock Market returns in India - An Analytical Study. Apeejay Journal of Management Sciences and Technology, 4(1). 